\title{
A Critical Review of the Corruption Literature
}

\author{
N N Tarun Chakravorty \\ Siberian Federal University
}

This study engages with new kinds of policies to combat corruption with real-life examples. Most of the corruption literature concentrates on the impact of corruption and is done at the macro-level. Studies on the causes and remedies are few. This article has focussed on remedial measures as well as theoretical issues, measurement issues, types of corruption, causes and effects. Using a descriptive method of research this study introduces some innovative ideas. I have redefined the actors in the agency structure, which is absolutely novel. Existing definitions are unclear or confusing. I suggest that tools have to be set up so that bureaucrats or politicians cannot be corrupt even if they want to. Policy makers and experts will be able to develop insights from this article.

Keywords: corruption, principal-agent-client, causes, effects, remedies

\section{INTRODUCTION}

Corruption has drawn growing attention in development discourses over the recent years (see Myrdal (1968), Nye (1967) for example). It is perceived as a major obstacle to development, especially in developing countries. The World Bank holds a similar notion and has taken this issue very seriously in terms of research and granting aid to recipient countries. The corruption issue is no longer confined within national boundaries; it is rather concerned with multi-national companies and aid agencies. While investing, multinational companies are affected by corruption in host countries. At the same time, there are events where multinational companies offer bribes to have contracts or other undue opportunities. Aid agencies are often found to be unsuccessful in bringing development outcomes owing to corruption in host countries.

Corruption may take various forms such as bribery, rent-seeking, kick-back, extortion, embezzlement and so on. It is, therefore, difficult to define corruption which may cover all the forms. Corruption is popularly defined as 'misuse of public offices for private gains' or 'the behaviour that deviates from formal duties because of private gains'. Definitions of corruption may have legal and moral dimensions as well.

Most of the studies conducted on corruption look mainly at the effects of corruption, but causes and remedies are more important. However, remedial measures certainly depend on the causes or, in other words, on the types of corruption. While there is no straightforward or universal solution to corruption, I discuss the remedial measures for the most common type of corruption.

In this paper, we shall discuss theoretical and empirical studies in order to understand the types, causes, effects of and remedies for corruption. The article proceeds in the following way: section 2 discusses the theoretical issues, section 3 the measurement issues, section 4 the types of corruption, section 5 the causes, section 6 effects, section 7 the remedial measure and finally, section 8 concludes. 


\section{THEORETICAL ISSUES}

Theories on corruption have emerged in the process of examining the agency structure where there are three parties: principal, agent and client. Principal refers to the person or body which owns the commodity; agent refers to the person who is assigned to hand over the commodity, and client refers to the person who is seeking the commodity to have. However, the meanings of these terms will change according to cases or perspectives. Some examples would make the agency relationships clear.

In a situation where a government minister assigns bureaucrats to distribute licenses among the people interested in undertaking to sell, say, a fertilizer to farmers. The minister who truly represents the mass people, the real owners of the wealth of a nation and voted the minister to power, is the principal (in fact, the people of the state are the principal, but the minister can be considered the principal as long as he truly represents the people), the bureaucracy - for clarity's sake, the secretary of the concerned ministry is the agent, and the people interested in buying licenses are the clients. If the minister does not truly represent the people and takes bribes from the license seekers through the secretary, then he is no longer the principal, rather becomes a part of the agent, which consists of all government officials involved in the process of distributing licenses. Here the voters or the body which is overseeing the activities of the ministry, for example, the parliamentary committee, can be considered the principal.

In a case where a regulatory authority assigns an inspector to check the level of pollution caused by firms, the regulatory authority is the principal, the inspector, the agent and the firm, the client.

When the commissioner of a tax region is given a target of collecting taxes, the tax inspector is the agent, the taxpayer the client, and the commissioner the principal.

Police become the agent while criminals, the client and the members of the society seeking law and order are the principal.

Corruption is said to take place when the agent cheats the principal by gaining monetarily through doing monetary favours to the clients.

Before we go for discussing theoretical causes of corruption, it needs to be emphasised that the principal is the one who wants a hundred percent fairness in distributing commodities to true clients. As soon as the body or person who apparently acts the role of principal indulges in seeking private gains at the cost of public loss, can no longer be considered a principal in a theoretical analysis.

Lack of information, conflicts of interests and absence of accountability are the causes of corruption. The fact that the principal lacks information and the agent is well-equipped with information, which puts the latter in an advantageous position, creates the scope for the agent to collude with the client and, thus, rent is extracted and shared between them.

In the agency structure, three categories of relationships between principal, agent and client usually exist on the basis of the amount of power and responsibilities enjoyed by the agent. First, the agent has the absolute power of information; the principal is in total darkness about the client. Regulatory enforcement, tax enforcement, policing, etc., fall into this category. Second, the principal has some power but allows the agent to choose an incentive mechanism for himself and also delegates the implementation plan to him. High-ranking bureaucrats enjoy this kind of opportunity, who exercise the power of policy design and fix their incentive packages. The third is a monopoly situation. Here all the power is transferred to the agent. Issuing licenses, permits, etc., fall in this category, where there are no guidelines about the distribution system (Mishra, 2005).

In the first type of framework, Tirole (1992) suggests that to prevent collusion between the agent and client, the principal can ask the agent to strictly follow his policy, put him into an incentive mechanism, and limit discretion for him.

In this type of situation, the inspector (agent) may produce a firm-favourable report by colluding with the firm owner and taking a part of the rent as a bribe; he can also cheat the firm by producing a firmunfavourable report when the firm chooses to be honest. In the second case, the firm becomes compelled to bribe the agent not to distort information. This behaviour of the agent is tantamount to extortion (Mishra, 2005). 
Banerjee (1997) describes a situation similar to the second type of agency structure. Here a bureaucrat is assigned to sell, e.g., permits imposing the condition that they must be sold to the high type clients (those who attach a higher value to it) first and the rest to the low type in order to achieve efficiency. Markets cannot ensure the sale of permits to high-type clients because an ability to pay might not match the price of the permit. Two agency problems would arise in this situation. First, neither the principal (government) nor the agent (bureaucrat) can get to know about the real value individuals attach to the permit; the low type will always claim to be the high type in order to get the permit. Second, the government does not know which mechanism the bureaucrat really applies; instead of ensuring efficiency by selling permits to the high type clients, he might indulge in seeking rents (Banerjee, 1997).

As a solution to the problems, the government can fix two prices: a high price, say, $\mathrm{P}_{\mathrm{H}}$ for high type, which guarantees the sale of the permit and a low price, say, $\mathrm{P}_{\mathrm{L}}$ for the low type, but these people would get a permit only after all high type clients get permits. If the bureaucrat has to follow this mechanism, he cannot extract rents; therefore, he introduces red tape, making it costlier for the high type to get a permit. Since it becomes costlier, not all of the high types can manage to get one. As a result, more permits are left for the low type for whom the bureaucrat charges higher prices, and buying permits at these prices is still less costly than maintaining red tape. That is why the low type clients do not pretend to be high type. Thus, incentive compatibility is still met, but the bureaucrat gathers money from permit seekers by extortion. This fact refutes the view that bribes can overcome red tape. In the case when the government does not have any control over the number of permits distributed, the bureaucrat turns out to be a monopolist who can create an artificial shortage in the supply of the commodity and thus can extort more payments from permits. The biggest problem with the bureaucracy is that it always tries to create a monopoly situation in the supply of goods the government wants to distribute among the people who deserve it and extracts rents (Mishra, 2005).

According to the "speed money" theory, corruption reduces delays in moving files in administrative offices and getting ahead in slow-moving queues for public services (Bardhan, 1997). According to Queuing models, the corrupt bureaucrat discriminates prices among clients with different time preferences. 'In the equilibrium queuing model with some special assumptions (Lui, 1985), derives bribing functions where the size of the bribe (decided by the briber, not the server of the queue) is linked to the opportunity costs of time for the individual client and shows that the bribing strategies will form a Nash equilibrium of this non-cooperative game that will minimize the waiting costs associated with the queue, thereby reducing the inefficiency in public administration' (Bardhan, 1997 p. 1323).

In general, centralized corruption has fewer adverse consequences for efficiency than decentralized bribe-taking because, in the former case, the bribee will internalize some of the distortionary effects of corruption (assuming similar powers at all levels to determine the overall rents in the system).

\section{MEASUREMENT ISSUES}

Measurement of corruption indices is a debatable issue inside and outside academia because these indices are constructed on the basis of perceptions of business people, experts and others having experience of paying bribes or knowledge in the system of bribery. Perceptions are always influenced by subjectivity. Corruption indices are not free from the heterogeneity specific to countries, societies and time periods either. Therefore, it cannot be guaranteed that analyses using this kind of perception indices are free from measurement biases. Yet, the Corruption Perception Index (CPI) of Transparency International and the Risk Index constructed by the International Country Risk Guide (ICRG) are considered the most acceptable indices in measuring corruption. They are acceptable in the sense that the articles using these indices are widely cited. This kind of article is huge in number. Mauro (1995), Aidt et al. (2008), You and Khagram (2005) are some of them.

The Corruption Perceptions Index (CPI) constructed by the Transparency International is a composite index, using data compiled or published by 13 surveys of business people and assessments by country analysts from 11 independent institutions: Africa Development Bank, Asian Development Bank, Bertelsmann Foundation, Economist Intelligence Unit, Freedom House, Global Insights, Institute for 
Management Development, Political and Economic Risk Consultancy, World Economic Forum and World Bank. A variable as a measure of corruption constructed by perception data is often criticized because, as is said, it is likely to suffer from perception biases. However, a combination of data sources increases its reliability, and since all the sources employ a homogeneous definition of 'extent of corruption' and the assessments are gathered from experienced respondents, the measure is close to the real one if not the real one itself (Knack \& Keefer, 1995).

The ICRG in rating countries in respect of various risks has included 22 variables in three subcategories: political risk, financial risk and economic risk. A separate index is constructed for each of these subcategories. The Political Risk Index is based on 100 points, Financial Risk on 50 points, and Economic Risk on 50 points. The composite country risk score is a weighted average of these 3 indices, while the weights are made by dividing the total points from the three indices by 2 . The composite scores, ranging from zero to 100, are then broken into categories from Very Low Risk (80 to 100 points) to Very High Risk (zero to 49.9 points). The Political Risk Rating includes 12 weighted variables covering both political and social attributes. The ICRG has produced a so-called "Type II" forecast in which its experts provide a current assessment, a one-year assessment, and a five-year assessment. The projections of future conditions are described as "best" and "worst". The ICRG provides ratings for 140 countries on a monthly basis and for 26 countries on an annual basis (Méndez \& Sepúlveda, 2006). Combining and averaging corruption data from two reliable sources have further diminished the possibility of the said biases leading this analysis towards a greater degree of accuracy.

\section{TYPES OF CORRUPTION}

Khan (2006) classifies corruption into four types: i) Neoclassical corruption; ii) 'Statist' corruption; iii) Political corruption and clientelism; and iv) Theft and primitive accumulation.

\section{Neoclassical Corruption}

'State' is seen as a machine of oppression by Marxists. In a similar fashion, classical economists believed that the very existence of the state creates the scope for its officials to create rents as it empowers them to exercise laws by which they can disrupt market operations. They take bribes from the citizens by helping them to create rents or by removing obstacles in getting things done (Rose-Ackerman, 1978, 1999; Klitgaard, 1988; Shleifer and Vishny, 1993).

Two drivers of this neoclassical corruption are identified. First, the existence of state laws enabling the public officials to create rents or removing obstacles from the way of having access to public service for the citizens. Second, the incentive for the public official to break laws, i.e., the opportunity cost of committing this illegal act should be low. By taking bribes, the government official takes the risk of punishment or losing the job, but these costs have to be less than the probable benefit he extracts from this corrupt behaviour. Examples of this kind of corrupt activities include unnecessary red tape, blocking files, helping business people in the creation of monopolies, releasing imported goods without tariffs or charging higher tariffs, providing subsidies to those who do not deserve or depriving those who really deserve subsidies etc. Bribes taken by low-ranking officials for forwarding an application or file, allowing people to visit the boss, providing information, misinterpreting regulations, and harassment done by constables or traffic police fall into this category of corruption (Khan, 2006).

Some authors like Leff (1964) and Huntington (1968) argue that bribery, as the second-best, helps businessmen to speed up their activities and thus have a positive impact on economic growth. This kind of view is affected by short-termism because as time goes, red tape, restrictions, and obstacles keep increasing, creating total chaos in the process hindering all economic activities as a whole (Myrdal, 1968: 937-51). Even in the second-best world, the probable good effects might not be confined in the expected areas when corruption becomes widespread (Rose-Ackerman, 1978). Moreover, the money spent in paying bribes could well be invested productively, value-added from which would obviously outweigh the gains from speeding up businesses by bribes. The consensus, in this regard, is against the view that corruption should exist to 'grease the wheel' and in order to abolish corruption, excessive restrictions, lengthy process, too much 
scrutiny and permissions from so many offices, and public official's ability to put obstacles have been proposed to be diminished significantly (Khan, 2006).

Besides the economic costs mentioned above, there are social costs of this kind of corruption as well. Each of the corrupt activities under this category creates deadweight losses for the society as well as incurring losses in economic efficiency by increasing transaction costs. This kind of loss causes further losses by reducing investments. Economic costs and these deadweight losses create an overall welfare loss in the economy (Khan, 2006).

\section{'Statist' Corruption}

When there are widespread market failures, state interventions may be beneficial. Centring these interventions, a lot of restrictions and rent creation take place, which may lead to second-best improvements. These rents are sometimes necessary for market operations and thus beneficial for economic growth (Khan, 2006). Stiglitz (1996) has found this sort of rent to be beneficial in the context of asymmetric information. The countries which developed lately are believed to owe to rents and interventions which were meant to acquire new technologies. Not only that, these are believed to have contributed to restoring political stability, which is again an essential factor for economic development (Khan, 2002, 2002b; Rodrik, 1995, 2003; Amsden, 1992; Wade, 1991; Khan and Jomo, 2000).

Unlike the case of neoclassical corruption rents, and interventions created by the state under this condition may have a net positive effect, which is supposed to mean that society would be worse off without this intervention and the corruption generated by this intervention. Of course, to have a positive effect, in this case, the state must be capable enough to make interventions beneficial, and make sure that the rentseeking following interventions be done under a legal framework. Lobbying, political contributions, etc., fall into the kind of rent-seeking activities under the legal framework (Khan, 2006).

\section{Political Corruption and Clientelism}

Governments in developing countries do not have enough resources or tax revenue to meet the demands for redistribution of wealth by political parties or interest groups. In pressing their demands, these parties and groups create chaos hindering the development process and making the existence of the ruling party in power difficult. To continue to be in power and carry on the development process, the government tries to restore political stability by creating scopes for opponents to extract rents through informal patron-client networks. This kind of illegal transfer of resources or rent extractions has contributed to the economic development of these developing countries (Khan, 2006).

\section{Theft and Primitive Accumulation}

Predatory corruption, i.e., personal gains by the use of power on weaker people in the form of grabbing natural resources owned by the state or by the powerless poor people of the society, is prevalent in almost all developing countries. Public officials may grab resources for themselves or assist others to do so. Theft done by public officials or helping citizens in doing that and having a share of the stolen property is also tantamount to corruption because they are using public office for private gains. It is the politically powerful people who captured the ownership of land, other natural resources and industries which are privatized during transitional periods. In most of the cases these people do not possess the natural qualities of businessmen or industrialists, i.e., they do not have the expertise to use these resources efficiently. Due to inefficient use, the owners of these assets cannot contribute enough to the revenue of the government or even if some of them earn taxable incomes, they do not pay tax. Therefore, the government cannot finance to give protection to their assets. In this situation, the owners of the assets keep gunmen from mafia groups and sometimes buy protection from the police who are well-linked with the mafia and share illegal incomes. This kind of private protection arrangement does not limit the asset owners to the protection of their assets. They also use these arrangements to grab resources from other owners who cannot afford to pay privately for their protection; of course, the public officials, mainly the police officers, help them do that in exchange for money (Khan, 2006). 
Non-market transfers, as referred by Marx (1867), which took place during the transition from feudalist states to capitalist states, involved plundering of resources by the powerful people; these primitive accumulations are nothing but corruption because they were done by public officials or by the aid of public officials (Khan, 2006).

\section{CAUSES}

In explaining the fact that corruption in South Asian countries, where democracy is absent or new, is wider than in western countries. Myrdal (1968) observes that on the one hand, profit motive and market habit have not developed in the economic sphere, strong motivations for private gains have developed in the public responsibility on the other in the former while in the latter all economic activities are motivated by profit and tendency to make private gains from holding public responsibility and power has remained suppressed. He further explains that the behavioural reactions, which are never considered for profit-making in the West, have created a market and thus lead to making a profit. This non-market behaviour in the economic sphere and profit-making tendency while acting on public responsibilities are prevalent in countries like South Asia because these countries have entered into capitalist societies much later than the Westerns.

The rise of corruption can be explained as a connection filling up the gap in the imperfect market where costs, revenues, profits, and losses are distorted due to irrational calculations of the actors of the market. This imperfection has given rise to informal sectors in the economy and informal exchanges in the formal sector where officials are supposed to promote market mechanisms but, in reality, slow market forces or distort markets compelling the actors of the market instead to pay extra to expedite or carry out economic activities (Myrdal, 2005).

Pluralism of the societies has been found as a cause of corruption because it has prevented the formation of undivided loyalty to the community as a whole in the public officials and politicians. Rather, these people in power have shown favouritism to certain groups with whom they have special relations based on religion, ethnicity, language, family, caste etc. Firm rules and punitive measures essential for building a wider loyalty were absent (Myrdal, 2005).

Myrdal (2005) has emphasized the evolution of a society in explaining corruption. Corruption has been bred on the changes that took place in the countries which won independence and transformed from colonial system to self-government. The repatriation of efficient and professional bureaucrats, take-over of positions by the inefficient local officers, and the introduction of discretionary controls were important among these changes. Discretionary powers create a strong vested interest group.

Per Capita GDP, schooling, political competition, the share of imports in GDP, the share of fuels, minerals and metals in total exports, and trade distance are seen to have an impact on the level of corruption. A one standard deviation increase in per capita GDP is seen to reduce corruption by 1.57 points. Schooling exerts a negative impact on corruption, although it is significant only at the 10 percent level. The effect of political competition on corruption is significant also at 10 percent level only, but the effect of this variable goes surprisingly against the intuition, i.e., it is seen to have a negative effect. One reason for this might be the fact that the study has used raw data of the countries with very low corruption and low political rights. One deviation increase in the share of imports decreases corruption by 0.47 points, which can be interpreted in the way that an increase in import share in the GDP means greater competition to be faced by local firms and greater competition reduces the scope to enjoy rents, which, in turn, reduces their ability to pay a bribe to bureaucrats. Exogenous factors like exports of fuel, minerals and metals create rents for domestic firms from abroad. The study shows that a one standard deviation rise in this category of export increases corruption by 0.37 points. How the level of corruption is impacted by trade distance is that the longer the way the world's leading exporters are situated, the more the domestic firms are protected from foreign competition, i.e., the less competition prevails in the local market, and lower competition increases corruption. A one standard deviation increase in the trade distance increases corruption by 0.51 points (Ades \& Di Tella, 1999). 
The extremely low salary of public officials is obviously a big reason for corruption. It was no way possible for low or medium-grade public servants to live in a town or city with the family paying for a rented house or in a government quarter with nominal subsidy, let alone afford children's education and medicare.

When it is the case that culprits and embezzlers of public funds have never been seen punished, politicians and officials from bottom to top have no fear of carrying on corrupt practices. A widespread and long history of corruption created a cynicism in society, which promoted corruption.

In Bangladesh, military governments and the so-called civil governments formed by generals tried to build a supporters' group of bureaucrats and politicians. In doing that, they allowed them to embezzle public funds. These supporters helped the military men to form political parties and used their embezzled money to buy party nominations and votes. After being elected to public posts, they not only collected the money they had spent but also gathered huge money to ensure re-election because election to a public post was totally dependent on how much money one could spend. Regimes of General Zia and General Ershad are perfect examples of promoting corruption in Bangladesh from 1976 to 1990.

A causal relation between military expenditure and corruption has been found by Hudson and Jones (2008) in their study, which is an extension and complement of Gupta et al. (2000) examining the linkage between military expenditure and corruption. An important finding of Gupta et al. (2000) is that corruption increases military spending as a proportion of both GDP and government spending. Unlike Gupta et al. (2000), Hudson et al. (2008) use corruption as the dependent variable, i.e., here causality flows from military expenditure to corruption. They find that the amount of military spending per soldier and arms imports causes corruption to increase. Corruption is seen to decline with GDP per capita. Bureaucratic quality, religious tensions and democratic accountability are other important factors having a direct relation with corruption, while the share of aid in GDP has an inverse relation with it (Hudson et al., 2008).

The absence of strong opposition parties in the state makes the members of the ruling party corrupt because they believe that they will continue to be re-elected and perpetuate their stay in power. The ruling party appoints their party members and supporters in every wing of the state machine, who help the ruling party come to power by rigging votes and embezzling public funds.

Competition has been seen as a strong determining factor of the level of corruption. Rose-Auckerman (1978) finds that if competition exists among the officers taking bribes would reduce the equilibrium amount of corruption because a kind of price bidding will take place among them. If competition in the product market is less, firms enjoy higher rents, which induces bureaucrats (e.g., tax inspector) to have control over them to indulge in corrupt behaviour. However, if the bureaucrat's incentive scheme is taken into account, the product market's competition might rather reduce bureaucrat's ability to take bribes from firms because higher rents would make them rewrite bureaucrat's contracts and spend money in an effort to control him. It means that competition might reduce corruption as well. We can, therefore, see that the effect of corruption is ambiguous (Ades et al., 1999).

Too much regulation is an important cause of corruption. The more regulations there are, the more scope for the bureaucrats to take a bribe. The World Bank publishes an index called 'ease of doing business' every year, which indicates the regulatory requirement in government offices. Here we can see that the value of the index is higher in countries where corruption is higher; for example, in Afghanistan, Bangladesh, Nigeria, Pakistan and India, this value is 173, 168, 131, 108 and 63, respectively. On the other hand, the value is low in countries where the level of corruption is low; for example, in New Zealand, it is 1, in Denmark, it is 4, in Norway, it is 9, and in Sweden, it is 10. The value of the index in Malaysia is only 12 , and Malaysia is the country that has achieved specular developments in its industrial sector and trade $\&$ commerce in the last four decades.

Svensson (2003) and Chen and Reinikka (1999), in their study, find that leaving the discretionary power with the bureaucrats is tantamount to giving them the opportunity to take a bribe. The discretionary power should be left with only the lawmakers who will make law after long discussions in the parliament, and before passing the law, the parliamentary committee has to listen to all the parties related to the issue. For example, if the law is regarding the garment industry, a parliamentary committee must listen to the workers 
belonging to the garment industry. Myrdal (1968) has mentioned discretionary power as a cause of corruption as it creates a strong vested interest group.

The bigger the size of the government, the more the scope for corruption, and the more decentralized the power structure of the government, the less the scope for corruption. If government spending is segmented into many layers, corruption is less likely to take place. All the research conducted in this area shows a similar result. Kotera et al. (2012) add democracy in their equation and find that corruption will fall if the size of the government is small only when there is democracy in the country. Theobald (1990: $p$. 127) finds that corrupt bureaucrats and politicians transfer resources to unproductive projects with a view to misappropriating the state funds, and this finding is also upheld in the research conducted by others. Zafarullah and Siddiquee (2001) conduct research on Bangladesh and find that due to dishonesty and inefficiency of the bureaucrats Bangladesh is wasting billions of dollars every year. The Asian Development Bank expresses a similar view and says that the limited resources of the state are being transferred to unproductive projects due to corruption in Bangladesh.

Research on corruption and the freedom of the press and media, and the independent judiciary occupies a lot of areas in Economics and Political Science. That without the freedom of the press and media and an independent judiciary, corruption cannot be combatted is the main findings of these research works. Participation of women in the labour force, parliament, and other divisions of the state may help to reduce corruption. These findings are supported by Swamy et al. (2001), Azfar et al. (2001), Dollar et al. (2001) and many others.

The correlation between corruption and political institutions and political systems has been widely discussed in Economics and Political Science. That democracy promotes human development is like an established truth and is supported by many studies like Dreze and Sen (1989), Boix (2001), Lake and Baum (2001), Brown and Mobarak (2009). Both the studies conducted by Ben Ali and Saha (2016) and Saha and Zhang (2017) find democracy conducive to human development, but it is true for developing countries or at the initial stage of development. Starting from North (1990), in many other later studies such as Butkiewicz and Yanikkaya (2006), Djezou (2014), Nawaz (2015), democratic institutions and governance have been found to be a determining factor of economic growth. Very recently, Acemoglu et al. (2019), using a panel of countries from 1960 to 2010, examined the impact of democracy on economic growth. Their estimate shows that democracy has a positive effect on GDP per capita and that its effect is significant and sizable. 'The effects are similar across different levels of development and appear to be driven by greater investments in capital, schooling, and health' (Acemoglu et al., 2019, p. 1).

There has been a lot of research on political connections, i.e., firms' connections with political parties and corruption. If the distribution of permit, contract, license and administrative tasks in government offices are done with political consideration or with a partisan viewpoint, economic growth is bound to be hampered because the most efficient firms which are already in the market might be deprived because of having no political connection. And the firms willing to enter the market will be prevented by syndicates. Faccio (2006), in his article, has made it clear. There is a huge incentive for firms to be connected with political parties. The politically connected firms will receive preferential treatment from the government in a number of forms. For example, he will buy a state-owned enterprise at a nominal price; he will receive a bank loan easily without collateral. He will pay less tax or no tax at all, and the regulatory requirement will be relaxed in his case etc. Shleifer and Vishny (1994) suggest that politicians take away much of the 'windfall gains' that the politically connected firms manage to gather.

\section{EFFECTS}

In recent times corruption has been examined and analyzed in both theoretical framework and empirical research methods, which has formed the basis for considerable attention in the economics literature. This stream of economics examines the determinants and implications of corruption for firm-level or economic growth through a combination of analytic, quantitative and qualitative research methods. Some studies have established causal relationships between corruption and economic growth. Many of the analytic works on corruption supported by empirics have evolved as theories over time, while some have remained just as 
empirical findings. In the literature, the debate on the effect of corruption has led to two opposing strands: efficiency-enhancing strand and efficiency-reducing strand.

\section{Negative Effects}

Most empirical studies find a negative relationship between corruption and macroeconomic variables like growth rate, FDI, flows of foreign aid, the openness of the economy, public expenditure, industrial policy etc.

Rose-Ackerman (1978) counters 'efficiency argument' putting her findings that corruption might appear to be helping growth in some areas/sectors, but once corruption is allowed to exist and go on, it would not be confined in those areas/sectors, would rather spread and the whole economy would be stagnant by corruption and no activities would take place without a bribe. Expectations of a higher bribe would make the corrupt officials wait and slow down the whole process.

Myrdal (1968, p. 952) presents the Indian experiences from Santhanam Committee Report on corruption that bribe-giving has become a custom in the course of offering government officials bribe by individuals years after years to move files on or do things fast; therefore, the handing over of a good, e.g., a license will be artificially delayed until a bribe is received. In the report, it is thus argued that corruption may even lead to more bureaucratic delays. What is interestingly new in the report is that speed money may avoid delay for an individual, but it increases red-tapism as part of the culture in the country, slowing down the whole economy in the end.

Cross-country analyses done by Mauro (1995) find corruption to be lowering private investment, thereby reducing economic growth, even in countries where bureaucratic regulations are very cumbersome in contrast with the findings of Leff (1964), Huntington (1968) mentioned above. Mauro (1995) also finds corrupt bureaucrats to create barriers to investment, entrepreneurship and innovation, delaying the distribution of public goods, thereby slowing down the whole process offsetting the positive effect of technological advances. Mauro (1995)'s findings are confirmed by Brunetti, Kisunko and Weder (1998) and Mo (2001).

Theobald (1990) describes a scenario which reveals the negative influence of corruption on investment, utilization of resources and so on, 'Corruption, in the diversion of public resources into the private sphere in the Third World, results in a significant squandering of scarce natural resources; investment decisions are distorted by corrupt interests, development projects are sited not where they are most needed but according to the mechanization of politicians who need to pay off the businessmen who have bank-rolled their election campaigns, tenders for government contracts are accepted not by economic criteria but on the basis of who will offer the largest bribe' (Theobald 1990, p. 127).

While FDI constitutes significant proportions of total investment in a country, corruption has been found to have a negative impact on FDI or capital inflow in the empirical studies done by (IMF, 2020), Lambsdorff and Cornelius (2000), Abed and Davoodi (2000) and Lambsdorff (2003).

Knack and Keefer (1995) report a significant negative impact of corruption. Knack and Keefer (1995) use 'security of property rights' and 'security of contract rights' as measures of quality of institutions, which, in turn, determines the corrupt behaviour of politicians. Using OLS regressions, they find that institutions that protect property rights have a positive impact on economic growth and investment, meaning that corruption reduces growth. Tanzi and Davoodi (2000), from a cross-section analysis of 97 countries, provide evidence for a fall in GDP growth due to corruption measured by the CPI index.

Lambsdorff (2003) experiments with the ratio of GDP to capital stock as a proxy for a country's average capital productivity on a sample of 69 countries controlling for the total capital stock and testing for various other variables and finds corruption to have a significant negative impact on this ratio.

The quality of public investments like infrastructure development, condition of paved roads, and power supply has been seen to be negatively affected by corruption in Tanzi and Davoodi (1998). Similarly, Gupta et al. (2002) show that inefficient government services are directly correlated with increasing corruption.

Méon and Sekkat (2005), after testing both the hypotheses of corruption- "greasing the wheels" and "sanding the wheels", report that corruption is most harmful to growth where governance is weak. Fisman and Svensson (2007), using a unique dataset from the Ugandan firm-level survey of 1997, examine how 
bribe and tax affect firm growth and find a negative effect of bribe payments on firm growth - an effect which is 2.5 times larger than that of taxation.

Nguyen and (Van Dijk, 2012) investigate the impact of corruption on firm growth using measures of corruption different from Svensson (2003) or Fisman and Svensson (2007). Instead of using bribes paid by firms themselves, Nguyen and Van Dijk (2012) use: '(i) the level of corruption severity in the local business environment as perceived by firms; and (ii) corruption as the choice to pay and the number of informal payments in accordance with industry practice as perceived by firms' (Nguyen and Van Dijk, 2012 p.2936). Using these measures of corruption, they find corruption to have a clear negative impact on the growth of private firms but no significant impact on that of state-owned firms.

Mauro (1995, p. 683), in his cross-country analysis, finds that 'if Bangladesh were able to increase the bureaucratic efficiency index by a one-standard-deviation, its investment rate would rise by almost five percentage points, and its yearly GDP growth rate would rise by over half a percentage point.' The World Bank, in its 2002 Report, says, in the absence of corruption, Bangladesh's growth would have been double. So, it is comprehensible that Bangladesh is deprived of its desired growth because of corruption.

Mauro (1997) who used corruption data provided by PRS and Gyimah-Brempong (2002) who used data from African countries, found an adverse impact of corruption on growth. Kumi et al. (2015) examine the effect of corruption on economic growth using the data of sub-Saharan Africa over 1998-2011. Corruption is seen to have this impact through gross fixed capital formation and labour force.

As for speed money, Gunnar Myrdal (1968), citing the 1964 Santhanam Committee on the Prevention of Corruption appointed by the Government of India, has argued that corrupt officials may, instead of speeding up, actually cause administrative delays in order to attract more bribes.

The control rights on the latter are often arbitrary and uncertain, leaving a lot of leeway for the bribee to renege on his understanding with the briber or to come back and demand another bribe.

Corruption has its adverse effects not just on static efficiency but also on investment and growth. Payment of bribes to get an investment license clearly reduces the incentive to invest (even apart from affecting the composition of investment, in view of the considerations of secrecy and uncertainty alluded to in the previous section).

\section{Positive Effects}

Some authors claim corruption to have some positive impact on economic growth in certain contexts. The efficiency-enhancing school advocated by Leff (1964), Huntington (1968), Lui (1985), Leys (1965) argues that corruption increases economic growth through two types of mechanisms: first, the money paid as bribe acts as 'speed money' or 'greasing wheel' enabling individuals to avoid bureaucratic delays; second, government officials who take bribes work harder to increase their 'earnings'. However, the first mechanism would make the corrupt activities of government officials become beneficial to growth only when bureaucratic regulations are too cumbersome, and corruption exists in the country widely and deeply (Rose-Ackerman, 1978). Khan (2006), Morgan (1964), Mankiw (2000) also find corruption essential or beneficial. According to the 'speed money' or 'greasing wheel' hypothesis, why corruption may be beneficial in a second-best world is the fact that distortions caused by ill-functioning institutions or inefficient bureaucracy which puts obstacles to investment or business can be circumvented by bribes. In other words, bribes may act as a trouble-saving device that would raise efficiency and finally promote investment and growth as they provide added incentives to bureaucrats to do their jobs (Méon and Sekkat 2005).

'Statist corruption' as described by Khan (2006) above is supposed to have this kind of effect. Rents and interventions created by the state in this category may have a net positive effect, which is supposed to mean that society would be worse off without this intervention and that corruption is generated by this intervention. Of course, to have a positive effect, in this case, the state must be capable enough to make interventions beneficial and make sure that the rent-seeking following interventions be done under a legal framework. Lobbying, political contributions, etc., fall into the kind of rent-seeking activities under the legal framework (Khan 2006). However, this kind of claim is not authenticated by econometric analyses using data. 
When corruption is pervasive and regulations are cumbersome, corruption may actually improve efficiency and help economies to grow, and the argument behind it is that additional distortions may lead to a welfare gain in the second-best world (Bardhan, 1997).

Another efficiency argument in favor of corruption is to look upon it as "speed money" which reduces delays in moving files in administrative offices and in getting ahead in slow-moving queues for public services.

According to the "speed money" theory, corruption reduces delays in moving files in administrative offices and in getting ahead in slow-moving queues for public services (Bardhan, 1997). According to Queuing models, the corrupt bureaucrat discriminates prices among clients with different time preferences. 'In the equilibrium queuing model with some special assumptions, Lui (1985) derives bribing functions where the size of the bribe (decided by the briber, not the server of the queue) is linked to the opportunity costs of time for the individual client and shows that the bribing strategies will form a Nash equilibrium of this non-cooperative game that will minimize the waiting costs associated with the queue, thereby reducing the inefficiency in public administration' (Bardhan, 1997 p. 1323).

In cases where regulations are excessive, government officials, if paid a bribe, would not enforce all the stipulated rules and thus will speed up economic activities for firms or businessmen. Here a bribe acts as a sort of deregulation and thus can amend the bureaucracy and the regulations (Huntington, 1968; Leff, 1964; Leys, 1964; Bayley, 1966; Méon and Sekkat, 2005).

Lui (1985), in his queuing model, shows that more efficient firms would agree to pay more for less red tape. The practice of exchanging bribes builds a system that leads to an efficient process of allocating licenses and government contracts, exerting a positive impact.

\section{REMEDIES}

In the light of the report submitted by the Santhanam Committee formed to carry out an investigation on corruption in India, the following remedies for corruption are put forward: Decision-making procedures have to be made much simpler and shorter in order to expedite economic activities. The discretionary powers of the people holding public responsibilities have to be decreased to the minimum possible levels. Remunerations of the civil servants at the lower end must be increased to an amount by which they can survive without indulging in illegal practices for extra earnings; their economic and social status have to be elevated so that the young generation with honest attitudes gets attracted to these jobs.

Paying higher-than-market clearing wages to public servants has also been advocated by Becker and Stigler (1974). Vigilance agencies and forces have to be formed of professionals and experts, and those against whom there is no question about their integrity. These agencies are to be made truly independent by law. The penal code and law-enforcement procedures have to be made stricter, and easily applicable, and punitive measures have to be made neutral and very prompt.

Not only the public servants but also those working in the private sector who offer bribes have to be punished and, in this regard, costs, revenues, profits and tax reports have to be made public. For example, a contractor who has got the construction contract to build a public bridge must be under a legal obligation to write every component of costs, revenue, profit in a big signboard on a daily basis. By the law of 'access to information,' any citizen of the country should be able to check the authenticity of these reports by asking for evidence and comparing the costs by the prevailing market prices. Not only that, any member of the public must have the right to see his tax reports and his other sources of income, his wealth, bank balances, etc.

Business enterprises must be strictly prohibited from subscribing to political parties, and doing so must be made a punishable crime by law. People who report unlawful activities to government departments must be protected. At the same time, reporting false allegations has to be made a punishable crime as well. Public sentiment has to be built against corruption, and an environment has to be created so that members of the society look down upon the corrupt people, for which social, professional, literary groups have to be formed. Organizations, media and individuals contributing to revealing corrupt activities and forming public sentiments against corruption must be honoured nationally. 
Although western countries have passed their time of the extreme level of corruption long back, businessmen or big companies from these countries have been contributing to the expansion of corruption in developing countries, namely by bribing the politicians and bureaucrats. The governments of western countries must investigate the activities of their businessmen and impose the same level of punishment for their corrupt activities abroad.

As a remedy to resist the agent to manipulate information for the principal and collude with the client, the introduction of information and supervision technology will be very effective. In the particular context of tax enforcement, greater automation and computerized cross-matching will prevent tax inspectors from distorting information and helping taxpayers to evade taxes (Mishra, 2005).

Policy suggestions to remove this kind of corruption is firstly, to privatize and liberalize the economy and to cut the size of the bureaucracy to the minimum; secondly, to increase the opportunity costs of being corrupt by raising salaries of public officials, to bring transparency in the allocation of public resources and to make the judiciary of the state effective so that stern punishment for corrupt activities may be ensured (Khan, 2006).

It is not the duty of economists to prescribe how to remove moral degradations or social diseases. It is already said that Economists look at corruption as a bureaucratic, institutional and political problem. As a cure for it, economists rather suggest setting some tools or instruments with a view to creating checks and balances or a kind of equilibrium in the state. Democracy and accountability, presence of an effective opposition in the parliament, freedom of press and media, freedom of speech, equal opportunity to preach all philosophies, an independent judiciary, independent election commission, independent human rights commission, etc., are these tools. Not only that, police and the inquiry commission will also have to be independent, and the recruitment procedure will have to be free, fair and unbiased; otherwise, corruption cannot be combatted.

\section{CONCLUDING REMARKS}

It has to be admitted that many aspects and issues about corruption have not been discussed in this article, namely hierarchies and organizational issues, debates on whether corruption is a persistent behaviour or not. Putting the agent in an incentive mechanism by the principal should also have been discussed elaborately.

Types, causes and effects of corruption require further investigations. In this regard, eliciting authentic information is a big problem. This author strongly suggests that government and private agencies build economic intelligence branches and 'access to information act' be passed in all countries and then information be exchanged across countries. As a remedy to the probable collusion between the agent and the client, a simple model is proposed by this author, which is beyond the scope of this paper. However, this model needs to be improved by stronger arguments and by giving a theoretical framework with mathematical tools.

A positive effect of corruption, as claimed by some authors, has already been questioned in this article, and the logic has been put forward for this. In fact, throughout the literature, support for the negative impact of corruption is clearly dominant and holding it as a fact, remedial measures have to be invented.

\section{ACKNOWLEDGEMENTS}

Dr. Qudrate Khoda, Dr. Subho Basu and two other unknown reviewers.

\section{REFERENCES}

Abed, G.T., \& Davoodi, H.R. (2000). Corruption, structural reforms, and economic performance in the transition economies. International Monetary Fund.

Acemoglu, D., Naidu, S., \& Restrepo, P.R. (2019). Democracy does cause growth. Journal of Political Economy, 127(1), 47-100. https://doi.org/10.1086/700936 
Ades, A., \& Di Tella, R. (1999). Rents, competition, and corruption. The American Economic Review, 89(4), 982-993. Retrieved from http://www.jstor.org/stable/pdfplus/117169.pdf?acceptTC=true

Aidt, T., Dutta, J., \& Sena, V. (2008). Governance regimes, corruption and growth: Theory and evidence. Journal of Comparative Economics, 36(2), 195-220. Retrieved from http://ac.els-cdn.com/ S0147596707000868/1-s2.0-S0147596707000868-main.pdf?_tid=3736ea9a-5678-11e2-8aaf00000aab0f6c\&acdnat $=13573086895 \mathrm{e} 58 \mathrm{ba} 20920 \mathrm{bb} 34 \mathrm{f} 79453 \mathrm{fec} 4 \mathrm{ce} 65 \mathrm{a} \mathrm{a}$

Amsden, A.H. (1992). Asia's next giant: South Korea and late industrialization. Oxford University Press on Demand.

Azfar, O., Lee, Y., \& Swamy, A. (2001). The causes and consequences of corruption. The Annals of the American Academy of Political and Social Science, 573(1), 42-56.

Banerjee, A.V. (1997). A theory of misgovernance. The Quarterly Journal of Economics, pp. 1289-1332.

Bardhan, P. (1997). Corruption and Development: A Review of Issues. Journal of Economic Literature, 35(3), 1320-1346. https://doi.org/10.4324/9781315126647-30

Bayley, D.H. (1966). The effects of corruption in a developing nation. The Western Political Quarterly, pp. 719-732.

Becker, G.S., \& Stigler, G.J. (1974). Law enforcement, malfeasance, and compensation of enforcers. The Journal of Legal Studies, 3(1), 1-18.

Ben Ali, M.S., \& Saha, S. (2016). Corruption and economic development. In M.S. Ben Ali (Ed.), Economic Development in the Middle East and North Africa: Challenges and Prospects (pp. 133-154). New York: Palgrave Macmillan.

Boix, C. (2001). Democracy, development, and the public sector. American Journal of Political Science, pp. 1-17.

Brown, D.S., \& Mobarak, A.M. (2009). The transforming power of democracy: Regime type and the distribution of electricity. American Political Science Review, 103(2), 193-213.

Brunetti, A., Kisunko, G., \& Weder, B. (1998). Credibility of rules and economic growth: Evidence from a worldwide survey of the private sector. The World Bank Economic Review, 12(3), 353-384.

Butkiewicz, J.L., \& Yanikkaya, H. (2006). Institutional quality and economic growth: Maintenance of the rule of law or democratic institutions, or both? Economic Modelling, 23(4), 648-661.

Chen, D., \& Reinikka, R. (1999). Business taxation in a low-revenue economy: A study on Uganda in comparison with neighboring countries. World Bank, Africa Region.

Djezou, W.B. (2014). The democracy and economic growth nexus: Empirical evidence from cote d'Ivoire. The European Journal of Comparative Economics, 11(2), 251.

Dollar, D., Fisman, R., \& Gatti, R. (2001). Are women really the "fairer" sex? Corruption and women in government. Journal of Economic Behavior \& Organization, 46(4), 423-429.

Dreze, J., \& Sen, A. (1989). Public action for social security: Foundations and strategy.

Faccio, M. (2006). Politically connected firms. American Economic Review, 96(1), 369-386. Retrieved from https://pubs.aeaweb.org/doi/pdfplus/10.1257/000282806776157704

Fisman, R., \& Svensson, J. (2007). Are corruption and taxation really harmful to growth? Firm level evidence. Journal of Development Economics, 83(1), 63-75. https://doi.org/10.1016/j.jdeveco.2005.09.009

Gupta, S., Davoodi, H., \& Alonso-Terme, R. (2002). Does corruption affect income inequality and poverty? Economics of Governance, 3(1), 23-45. Retrieved from http://download.springer.com/static/pdf/884/art\%253A10.1007\%252Fs101010100039.pdf?auth66 $=1413827802$ b6fdca2dd19b3acb7403e64c19f1052e\&ext=.pdf

Gupta, S., De Mello, L., \& Sharan, R. (2000). Corruption and military spending. International Monetary Fund.

Gyimah-Brempong, K. (2002). Corruption, economic growth, and income inequality in Africa. Economics of Governance, 3(3), 183-209.

Hudson, J., \& Jones, P. (2008). Corruption and military expenditure: At 'no cost to the king.' Defence and Peace Economics, 19(6), 387-403.

Huntington, S.P. (1968). Political Order in Changing Societies. New Haven, CT: Yale University Press. 
IMF. (2020, June). World Economic Outlook Update. $\operatorname{Imf},(2), 6$. Retrieved from https://www.imf.org/en/Publications/WEO/Issues/2020/06/24/WEOUpdateJune2020

Khan, M. (2006). Determinants of corruption in developing countries: The limits of conventional economic analysis. International Handbook on the Economics of Corruption, pp. 216-244. Retrieved from https://eprints.soas.ac.uk/11680/1/BD LAO.pdf

Khan, M.H. (2002a). CORRUPTION AND GOVERNANCE IN EARLY CAPITALISM: WORLD BANK STRATEGIES AND THEIR LIMITATIONS. In Reinventing the World Bank (pp. 164184). Retrieved from https://eprints.soas.ac.uk/2432/1/Corruption_in_Pincus.pdf

Khan, M.H. (2002b). State failure in developing countries and strategies of institutional reform. $A B C D E$ Conference Europe, Oslo. Citeseer.

Khan, M.H., \& Jomo, K.S. (2000). Rents, rent-seeking and economic development: Theory and evidence in Asia. In M.H. Khan \& K.S. Jomo (Eds.). Cambridge: Cambridge University Press.

Klitgaard, R. (1988). Controlling corruption. University of California press.

Knack, S., \& Keefer, P. (1995). Institutions and economic performance: Cross-country tests using alternative institutional measures. Economics \& Politics, 7(3), 207-227.

Kotera, G., Okada, K., \& Samreth, S. (2012). Government size, democracy, and corruption: An empirical investigation. Economic Modelling, 29(6), 2340-2348.

Kumi, E., Yeboah, T., \& Muazu, I. (2015). Greasing or Sanding the Wheels? Effect of Corruption on Economic Growth in sub-Saharan Africa. African Journal of Economic and Sustainable Development.

Lake, D.A., \& Baum, M.A. (2001). The invisible hand of democracy: Political control and the provision of public services. Comparative Political Studies, 34(6), 587-621.

Lambsdorff, J.G., \& Cornelius, P. (2000). Corruption, foreign investment and growth. The Africa Competitiveness Report, 2001, 70-78.

Lambsdorff, J.G. (2003). How corruption affects productivity. Kyklos, 56(4), 457-474.

Leff, N.H. (1964). Economic development through bureaucratic corruption. American Behavioral Scientist, 8(3), 8-14.

Leys, C. (1965). What is the Problem about Corruption? The Journal of Modern African Studies, 3(2), 215-230.

Lui, F.T. (1985). An equilibrium queuing model of bribery. The Journal of Political Economy, 93(4), 760-781. Retrieved from http://www.jstor.org/stable/pdfplus/1832136.pdf?acceptTC=true

Mankiw, N.G. (2000). Principles of Economics (2nd ed.). Fort Worth: Harcourt College Publishers.

Marx, K. (1867). Das Kapital. Verlag von Otto Meisner.

Mauro, P. (1995). Corruption and Growth. Quarterly Journal of Economics, 110(3), 681-712. https://doi.org/10.2307/2946696

Mauro, P. (1997). The Effect of Corruption on Growth, Investment and Government Expenditure: A cross country Analysis. Corruption and Global Economy.

Méndez, F., \& Sepúlveda, F. (2006). Corruption, growth and political regimes: cross country evidence. European Journal of Political Economy, 22(1), 82-98. Retrieved from http://ac.elscdn.com/S0176268005000443/1-s2.0-S0176268005000443-main.pdf? tid=5ebb13ae-be36-11e28dbb-00000aacb361\&acdnat=1368715330_4af50bb20c86f9ae3113b928a3f4d7bd

Méon, P-G., \& Sekkat, K. (2005). Does corruption grease or sand the wheels of growth? Public Choice, 122(1-2), 69-97. Retrieved from http://download.springer.com/static/pdf/415/art\%253A10.1007\%252Fs11127-005-39880.pdf?auth66=1411635019_3f9f1cdd1d5d0f48349ac3002ad6c1a0\&ext=.pdf

Mishra, A. (2005). The economics of corruption. Oxford University Press.

Mo, P.H. (2001). Corruption and economic growth. Journal of Comparative Economics, 29(1), 66-79. Retrieved from http://ac.els-cdn.com/S0147596700917037/1-s2.0-S0147596700917037main.pdf?_tid=ba55fafc-cbcf-11e2-804800000aacb360\&acdnat $=1370210562$ f28efc33a2422309f31456f7f70dfb63 
Morgan, T. (1964). The theory of error in centrally-directed economic systems. The Quarterly Journal of Economics, pp. 395-419.

Myrdal, G. (1968). Asian Drama, an Inquiry Into the Poverty of Nations.

Nawaz, S. (2015). Growth effects of institutions: A disaggregated analysis. Economic Modelling, 45, $118-126$.

Nguyen, T.T., \& Van Dijk, M.A. (2012). Corruption, growth, and governance: Private vs. state-owned firms in Vietnam. Journal of Banking \& Finance, 36(11), 2935-2948.

North, D. (1990). Institutions, Institutional Change, and Economic Performance. Cambridge and London: Cambridge University Press.

Nye, J.S. (1967). Corruption and political development: A cost-benefit analysis. The American Political Science Review, pp. 417-427. Retrieved from http://www.jstor.org/stable/pdfplus/1953254.pdf?acceptTC=true

Rodrik, D. (1995). Getting interventions right: How South Korea and Taiwan grew rich. Economic Policy, 10(20), 53-107.

Rodrik, D. (2003). Institutions, integration, and geography: In search of the deep determinants of economic growth. In Search of Prosperity: Analytic Country Studies on Growth, Princeton University Press, Princeton, NJ.

Rose-Ackerman, S. (1978). Corruption: A study in political economy. Academic Press New York.

Rose-Ackerman, S. (1999). Corruption and government: Causes, consequences, and reform. Cambridge University Press.

Saha, S., \& Zhang, Z. (2017). Democracy-growth nexus and its interaction effect on human development: A cross-national analysis. Economic Modelling, 63, 304-310.

Shleifer, A., \& Vishny, R. (1993). Corruption 599-618. Quarterly Journal of Economics, (108), 599-618.

Shleifer, A., \& Vishny, R.W. (1994). Politicians and firms. The Quarterly Journal of Economics, pp. 995-1025. Retrieved from http://www.jstor.org/stable/pdfplus/2118354.pdf?acceptTC=true

Stiglitz, J.E. (1996). Whither socialism? MIT press.

Svensson, J. (2003). Who Must Pay Bribes and How Much? Evidence from a Cross Section of Firms. The Quarterly Journal of Economics, 118(1), 207-230. https://doi.org/https://doi.org/10.1162/00335530360535180

Svensson, J. (2003). Who Must Pay Bribes and How Much? Evidence from a Cross Section of Firms. The Quarterly Journal of Economics, 118(1), 207-230. Retrieved from http://www.jstor.org/stable/pdfplus/25053902.pdf?acceptTC=true

Swamy, A., Knack, S., Lee, Y., \& Azfar, O. (2001). Gender and corruption. Journal of Development Economics, 64(1), 25-55.

Tanzi, V., \& Davoodi, H. (1998). Corruption, public investment, and growth. Springer.

Tanzi, V., \& Davoodi, H.R. (2000). Corruption, growth, and public finances.

Theobald, R. (1990). What is Corruption? In Corruption, development and underdevelopment (pp. 1-18). Springer.

Tirole, J. (1992). Persistence of corruption.

Wade, R. (1991). GOVERNING THE MARKET ECONOMIC THEORY AND THE ROLE OF GOVERNMENT IN EAST ASIAN INDUSTRIALISATION. Princeton University Press.

You, J-S., \& Khagram, S. (2005). A comparative study of inequality and corruption. American Sociological Review, 70(1), 136-157. Retrieved from http://asr.sagepub.com/content/70/1/136.full.pdf

Zafarullah, H., \& Siddiquee, N.A. (2001). Dissecting public sector corruption in Bangladesh: Issues and problems of control. Public Organization Review, 1(4), 465-486. 